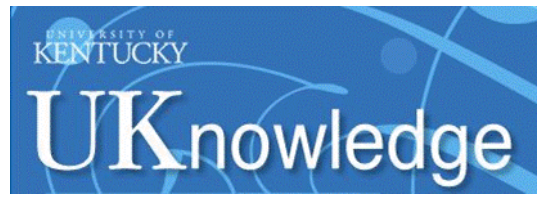

University of Kentucky

UKnowledge

\title{
4-2013
}

\section{Biodistribution and Biopersistence of Ceria Engineered Nanomaterials: Size Dependence}

\author{
Robert A. Yokel \\ University of Kentucky, ryokel@email.uky.edu \\ Michael T. Tseng \\ University of Louisville \\ Mo Dan \\ University of Kentucky, mo.dan@uky.edu \\ Jason M. Unrine \\ University of Kentucky, jason.unrine@uky.edu
}

See next page for additional authors

Right click to open a feedback form in a new tab to let us know how this document benefits you. Follow this and additional works at: https://uknowledge.uky.edu/ps_facpub

Part of the Pharmacy and Pharmaceutical Sciences Commons 
Biodistribution and Biopersistence of Ceria Engineered Nanomaterials: Size Dependence

Digital Object Identifier (DOI)

https://doi.org/10.1016/j.nano.2012.08.002

Notes/Citation Information

Published in Nanomedicine, v. 9, issue 3.

Copyright @ 2013 Elsevier Inc.

(c) 2013. This manuscript version is made available under the CC-BY-NC-ND 4.0 license

https://creativecommons.org/licenses/by-nc-nd/4.0/.

The document available for download is the authors' post-peer-review final draft of the article.

Authors

Robert A. Yokel, Michael T. Tseng, Mo Dan, Jason M. Unrine, Uschi M. Graham, Peng Wu, and Eric A. Grulke 
Biodistribution and biopersistence of ceria engineered nanomaterials: Size dependence

Robert A. Yokel, PhD, ${ }^{1,2^{*}}$, Michael T. Tseng, $\mathrm{PhD}^{6}$, Mo Dan, $\mathrm{MS}{ }^{1,2}$, Jason M. Unrine, $\mathrm{PhD}^{3}$, Uschi M. Graham, $\mathrm{PhD}^{4}$, Peng Wu, $\mathrm{PhD}^{5}$, Eric A. Grulke, $\mathrm{PhD}^{5}$

${ }^{1}$ Pharmaceutical Sciences, ${ }^{2}$ Graduate Center for Toxicology, ${ }^{3}$ Plant and Soil Sciences, ${ }^{4}$ Center for Applied Energy Research, ${ }^{5}$ Chemical \& Materials Engineering, University of Kentucky, Lexington, $\mathrm{KY} ;{ }^{6}$ Departments of Anatomical Sciences \& Neurobiology, University of Louisville, Louisville, KY.

Short title: Nanoceria biodistribution and persistence

${ }^{*}$ Corresponding author:

Robert A. Yokel, Ph.D.

Department of Pharmaceutical Sciences

335 Biopharmaceutical Complex (College of Pharmacy) Building

College of Pharmacy

University of Kentucky Academic Medical Center

Lexington, KY, 40536-0596

phone: 859-257-4855

fax: 859-257-7564

e-mail: ryokel@email.uky.edu 


\title{
Conflict of interest disclosure:
}

None of the authors has a financial conflict of interest related to this research. No writing assistance was utilized in the production of this manuscript.

\section{Sources of support:}

This work was supported by United States Environmental Protection Agency Science to Achieve Results [grant number RD-833772]. Although the research described in this article has been funded wholly or in part by the United States Environmental Protection Agency through STAR Grant RD-833772, it has not been subjected to the Agency's required peer and policy review and therefore does not necessarily reflect the views of the Agency and no official endorsement should be inferred.

Abstract word count: 98

Complete manuscript word count: 4150

Number of references: 53

Number of figures: 4; Number of tables: 2

\author{
Abbreviations: \\ BBB blood-brain barrier \\ ENM engineered nanomaterial \\ HRP horseradish peroxidase \\ ICP-MS inductively coupled plasma mass spectrometry \\ MDL method detection limit
}




\section{Abstract:}

The aims were to determine the biodistribution, translocation, and persistence of nanoceria in the brain and selected peripheral organs. Nanoceria is being studied as an anti-oxidant therapeutic. Five, 15, 30, or $55 \mathrm{~nm}$ ceria was iv infused into rats which were terminated 1, 20, or $720 \mathrm{~h}$ later. Cerium was determined in blood, brain, liver, and spleen. Liver and spleen contained a large percentage of the dose, from which there was no significant clearance over $720 \mathrm{~h}$, associated with adverse changes. Very little nanoceria entered brain parenchyma. The results suggest brain delivery of nanoceria will be a challenge. 


\section{Introduction:}

Nanotechnology has the potential to revolutionize drug delivery and manufactured products, leading to greater human engineered nanomaterial (ENM) exposure. This requires understanding of ENM pharmacokinetics and toxicity. Ceria (a.k.a.: $\mathrm{CeO}_{2}$, cerium oxide) ENMs have current commercial uses and potential medical applications. Major industrial uses are as a diesel fuel additive to catalyze combustion and decrease combustion temperature and in chemical-mechanical planarization (integrated circuit manufacture) ${ }^{1}$. Ceria ENMs are expected to have future application in fuel cells and batteries. Ceria redox activity creates the potential to reduce reactive oxygen and nitrogen species (ROS and RNS)-induced disorders, providing potential as a therapeutic agent. This has been demonstrated in numerous studies in which oxidative stress was induced (Table 1). On the other hand, studies have demonstrated that nanoceria redox activity can increase oxidative stress, the major untoward effect of ENMs (Table 1). However, these studies do not inform about ceria ENM distribution in animals, or its ability to enter the brain.

The extent of ceria ENM uptake from the gastrointestinal tract is very low, producing very small increases in organ cerium. Ceria was detected in lung and spleen, but not brain, heart, kidney, or liver of mice after 5 weekly oral doses of a 3 to $5 \mathrm{~nm}$ ceria $(0.5 \mathrm{mg} / \mathrm{kg} ; 2900 \mathrm{nmol} / \mathrm{kg})^{2}{ }^{2}{ }^{1}$ Oral administration of a $7 \mathrm{~nm}$ ceria $(\sim 5 \mathrm{mg} / \mathrm{kg} ; 29,000 \mathrm{nmol} / \mathrm{kg})$, resulted in $\sim 1 \times 10^{-4} \%$ of the dose in the liver and $\sim 1 \times 10^{-6}$ to $1 \times 10^{-5} \%$ in the brain, heart, kidney, lung, spleen, and testicle 1 to 7 days later ${ }^{3}$. Single oral administration of $30 \mathrm{~nm}$ ceria $(0.1 \mathrm{~g} / \mathrm{kg} ; 580,000$

1: Doses of ceria ENMs, reported or used in this work as mass ceria ENM/body weight, are also expressed in ceria ENM molarity, to facilitate comparison among studies, particularly in vitro to in vivo. 
$\mathrm{nmol} / \mathrm{kg}$ ) resulted in $\sim 2$ to $4 \times 10^{-3} \%$ of the dose in the brain, kidney, liver, lung, spleen, and testicle 1 to 14 days later, and after a larger dose $(5 \mathrm{~g} / \mathrm{kg} ; 29,000,000 \mathrm{nmol} / \mathrm{kg})$ proportionally more in the lung than other sampled organs ( 5 to $35 \times 10^{-4} \%$ of the dose) ${ }^{4}$. Uptake of $7 \mathrm{~nm}$ ceria $(0.2 \mathrm{mg} ; 1160 \mathrm{nmol})$ from the lung resulted in translocation into the central compartment (blood) and organs, including $\sim 1 \times 10^{-5}, 1 \times 10^{-4}, 1 \times 10^{-3}, 1 \times 10^{-2}$, and $1 \times 10^{-1} \%$ of the dose in the brain, heart and testicle, kidney, spleen, and liver, respectively, 28 days later ${ }^{3}$. Although cerium was detected in the brain after ceria ENM oral administration, intratracheal instillation and inhalation ${ }^{3-5}$, its distribution into brain parenchyma was not reported. These results suggest the therapeutic use of ceria ENM for brain disorders might require a route of administration other than oral or inhalation.

Intravenous injection of 3 to $5 \mathrm{~nm}$ ceria $(0.1$ or $0.5 \mathrm{mg} / \mathrm{kg}$; 580 or $2900 \mathrm{nmol} / \mathrm{kg}$ ) on Days 1 and 15 resulted in 100 to $200 \mathrm{~nm}$ electron-dense cerium-suspect granules in hepatocytes and renal tubular cells on Day 30. Cerium in other tissues was not reported ${ }^{6}$. A previous study showed considerable $30 \mathrm{~nm}$ commercial (platelet shaped) ceria retention in the liver and spleen, with much less in the brain, 1 and $20 \mathrm{~h}$ after iv administration of 50 to $750 \mathrm{mg} / \mathrm{kg}(290,000$ to $4,350,000 \mathrm{nmol} / \mathrm{kg})^{7}$. Similarly, liver and spleen contained much more $30 \mathrm{~nm}$ ceria ENM up to 90 days after an $85 \mathrm{mg} / \mathrm{kg}(495,000 \mathrm{nmol} / \mathrm{kg})$ iv dose ${ }^{8}$. Cerium was not detected in brain 1 week after 5 weekly $2910 \mathrm{nmol} / \mathrm{kg} 3$ to $5 \mathrm{~nm}$ ceria iv or ip administrations ${ }^{2}$. There is little known about the effects of ceria ENM size on its distribution in the mammal. The need for in vivo studies that examine the biokinetics and toxicity of ceria ENMs was identified ${ }^{1}$. For ceria ENM to be used as a therapeutic agent to treat neurodegenerative diseases, it presumably needs to enter the central nervous system. 
The objectives of the present research were to ascertain the effect of ENM size on distribution into selected organs, including the brain and ENM translocation up to 30 days (720 h) after a single iv ceria ENM infusion. This study addresses the longer term fate of the 4 sizes of citratecoated ceria ENMs we studied for their distribution within, and elimination from, blood ${ }^{9}$, focusing on their distribution and persistence in the brain, liver and spleen. 


\section{Methods:}

The ceria ENMs studied:

Five, 15, 30, and $55 \mathrm{~nm}$ nominal diameter citrate-capped ceria ENMs were synthesized and extensively characterized in house. Synthesis and characterization methods and results are described in the Supplemental Information. Based on preliminary studies described in the Supplemental Information, target doses were $100 \mathrm{mg}$ ceria ENM/kg for the 5, 15, and $30 \mathrm{~nm}$ ceria, and $50 \mathrm{mg} / \mathrm{kg}$ for the $55 \mathrm{~nm}$ ceria ENM. Based on cerium analysis in representative aliquots of the dosing material, the delivered doses were $85,70,85$, and $50 \mathrm{mg} / \mathrm{kg}(495,000$, $410,000,495,000$, and $290,000 \mathrm{nmol} / \mathrm{kg}$ ) for the $5,15,30$, and $55 \mathrm{~nm}$ ceria, respectively. This large ceria exposure was utilized to enhance our ability to detect cerium in the blood and organs up to 30 days after the single ceria ENM infusion.

\section{Animals:}

This study reports results from 126 male Sprague Dawley rats, weighing $333 \pm 35 \mathrm{~g}$ (mean \pm SD) ( 75 days old). Procedures to prepare the rats for iv ceria ENM infusion, preliminary studies to identify the ceria ENM dose for this work, methods to determine blood-brain barrier (BBB) integrity, organ and blood collection and processing procedures, cerum quantification methods, and light and electron microscopic assessment methods are described in the Supplemental Information. The rats were obtained from Harlan, Indianapolis, IN. They were housed individually prior to study and after cannulae removal (a few days after the iv infusion) in the University of Kentucky Division of Laboratory Animal Resources facility under a 12:12 $\mathrm{h}$ light:dark cycle at $70 \pm 8^{\circ} \mathrm{F}$ and 30 to $70 \%$ humidity. The rats had free access to 2018 Harlan diet and reverse osmosis water. Animal work was approved by the University of Kentucky 
Institutional Animal Care and Use Committee. The research was conducted in accordance with the Guiding Principles in the Use of Animals in Toxicology (http://www.toxicology.org/ai/air/air6.asp).

Data and statistical analysis:

Cerium concentrations below the method detection limit (MDL) were assigned $50 \%$ of the MDL and included in the statistical analysis as such. The percentage of the ceria ENM dose in the brain, liver, and spleen was calculated as cerium concentration times organ weight divided by the ceria ENM dose, which was based on cerium quantification in the dosing dispersion (determined by inductively coupled plasma mass spectrometry (ICP-MS)) times the dose volume. The percentage of the ceria dose in blood was based on a vascular volume of $7 \%$ of the rat's body weight (http://oacu.od.nih.gov/ARAC/Bleeding.pdf). Outliers in blood and tissue cerium concentration results identified by the Grubb's test (http://www.graphpad.com/quickcalcs/Grubbs1.cfm) were not used in data analysis.

Statistical comparison of \% of the ceria ENM dose in blood, brain, liver, and spleen of the control rats for each of the 4 treatment (ceria ENM size) groups was conducted using one-way ANOVA followed by Tukey's post-hoc test and found to not be significant. Results of all control rats for blood and each organ were merged and compared to the \% of the ceria ENM dose in treated rats by Dunnett's test; and within blood or an organ across termination times for each of the 4 ceria ENMs by ANOVA with Tukey's post-hoc test or two-tailed unpaired t tests. Comparison of the \% of the ceria ENM dose in blood or an organ at the same time following infusion of the 4 ceria ENM sizes was conducted using one-way ANOVAs followed by Tukey's 
post-hoc tests. Results from control and treated rats were compared for brain BBB marker concentration by one-tailed unpaired $t$ tests. Significance was accepted at $p<0.05$, except for the mass amount of cerium in the blood or organs as a percentage of the ceria dose, for which alpha was adjusted to $0.05 / 10$ to correct for the multiple comparisons. Results are reported as mean \pm S.D. 


\section{Results:}

Characterization of nanomaterials should include composition, morphology (average primary particle size and distribution, shape, and structure), surface properties (charge, coatings), and agglomeration in relevant media. Table 2 and Figures 1 and 2 show this information for the ceria ENMs studied. All samples were crystalline (X-ray diffraction, confirmed by TEM). TEM verified that the primary particles were distinct and not aggregated.

The primary particle sizes were determined by counting 50 to 100 particles in TEM images and using a lognormal function to model the number-based cumulative particle size distribution, reported as Average Primary Particle Size: TEM in Table 2. Cumulative data and model distributions are shown in Figure 1A. The probability density functions (computed from the lognormal models; Figure 1B) show that the 5,15 , and $55 \mathrm{~nm}$ materials were mutually exclusive with respect to primary particle size, whereas the $30 \mathrm{~nm}$ ceria had significant overlaps with the 15 and the $55 \mathrm{~nm}$ ENMs.

Specific surface area measurements can be used as confirmation of primary particle size. Results of BET surface determination for the 5,15 , and $30 \mathrm{~nm}$ ceria ENMs are shown in Table 2 , and were converted to average primary particle size (square brackets). In general, there is good agreement between the primary particle size averages determined by TEM and surface area. The number-based primary particle size distribution was used to compute the Sauter mean diameter $\left(\mathrm{d}_{32}\right)$, a surface area-based average (curly brackets under the TEM data), which corresponded well with the BET-determined average particle sizes. High surface area 
relative to that expected from the primary particle size might identify internal porosity. None of these materials appears to have internal porosity, consistent with their crystal morphology.

All ceria ENMs had surface citrate to aid aqueous media dispersion and reduce agglomeration (Table 2). All of these ENMs were expected to form stable dispersions in water (zeta potentials were $<-30 \mathrm{mV}$ ) (Table 2). Figure 2 shows number- and volume-based particle size distributions for the ceria ENMs in water, measured using dynamic light scattering and evaluated using the multimodal feature, which helps identify fractions with different particle sizes. The number-based distributions are monomodal, but all are somewhat larger than those generated from TEM measurements, suggesting possible nanoparticle agglomeration in water. Volume-based distributions in Figure 2 correspond to the conditions in the dose solution; most of the nanoceria mass will be associated with larger structures. These volume-based distributions show the presence of agglomerates much larger than the primary nanoparticles. In general, there can be a dynamic equilibrium between the agglomerates and primary nanoparticles in water. Therefore, agglomeration would not necessarily prevent movement of nanoceria across biological barriers, but it could reduce the rate.

Necropsy observation of the rats that received the $55 \mathrm{~nm}$ ceria ENM revealed a white deposit in the vena cava at the tip of the cannula that infused the ceria, indicating that a significant amount of ceria was deposited there during its infusion, and did not circulate in the blood. This was presumably due to the presence of the larger sized particles in this ENM and its lower extent of surface citrate coating. 
Of the 216 samples from control rats analyzed for cerium, 47 were above the MDL of 0.089 $\mathrm{mg} / \mathrm{kg}$ for tissue and $0.018 \mathrm{mg} / \mathrm{l}$ for blood. Ten were outliers by the Grubb's test. Of the 278 samples from ceria ENM treated-rats analyzed for cerium, all but 27 were above the MDL; 7 were blood samples from rats 30 days after the 30 or $55 \mathrm{~nm}$ ENMs and 20 were brain samples. Samples having less than the MDL value in ENM-treated rats reflect the low cerium concentration in blood 30 days after ceria ENM administration and in brain at all times. This can be seen in Figure 3 which shows the percentage of the ceria dose in blood, brain, liver, or spleen after ceria ENM treatment. For all of the control rats, the mean amount of cerium in blood, brain, liver, and spleen, expressed as a \% of the ceria dose given to the treated rats, was $0.003,0.001,0.0004$ and 0.04 , respectively. Figure 3 also shows significant differences of the ceria dose in blood or organs between times after a ceria ENM administration. There were no significant decreases of $\mathrm{Ce}$ in the liver or spleen over time. To the contrary, the percentage of the ceria dose in the spleen significantly increased over time after administration of the 15 and $30 \mathrm{~nm}$ ceria. The sum of the percentages of the ceria dose in the blood and 3 organs sampled accounted for 53 to $62 \%, 36$ to $38 \%, 41$ to $45 \%$, and 13 to $24 \%$ of the $5,15,30$, and $55 \mathrm{~nm}$ ceria ENM doses, respectively. As appreciable fecal and urinary cerium ENM excretion were not seen ${ }^{2,8}$, the remainder of the dose was evidently in un-sampled sites.

There was a significantly greater $\%$ of the $5 \mathrm{~nm}$ ceria dose in blood 1 and $20 \mathrm{~h}$ after infusion than the other 3 ceria ENM sizes. Brain had a significantly greater $\%$ of the $5 \mathrm{~nm}$ ceria dose than the $30 \mathrm{~nm}$ ceria at all times. The $\%$ of the $55 \mathrm{~nm}$ ceria dose was less in brain, spleen, and liver $20 \mathrm{~h}$ after infusion than after the smaller sized ceria ENMs. The spleen contained 
significantly less of the total dose of the $5 \mathrm{~nm}$ than the $15 \mathrm{~nm}$ ceria at 15 days, whereas the liver contained more of the 5 than $30 \mathrm{~nm}$ ceria at $20 \mathrm{~h}$.

Brain fluorescein was greater in all ceria-treated compared to control rats except for the rats that received $5 \mathrm{~nm}$ ceria $20 \mathrm{~h}$ after dosing, but only reached statistical significance in rats that received $30 \mathrm{~nm}$ ceria evaluated $20 \mathrm{~h}$ after dosing. Brain horseradish peroxidase was greater in all ceria-treated compared to control rats except for those that received the $55 \mathrm{~nm}$ ceria and were evaluated after $20 \mathrm{~h}$, but only approached statistical significance $(p=0.06)$ for the rats the received $5 \mathrm{~nm}$ ceria and were evaluated after $20 \mathrm{~h}$.

In addition, many ceria-treated rats that received the 5 or $30 \mathrm{~nm}$ ENM showed punctate white specs on the spleen surface 30 days after ceria infusion that appeared to be similar to deposits observed in the vena cava at the infusion site and were found to be ceria agglomerations. Two peripheral organs rich in reticuloendothelial cells, the liver and spleen, showed a large retention of nanoceria. Intra-sinusoidal cell aggregates were formed by ceria-containing Kupffer cells and adherent mononucleated cells. Ultrastructural study demonstrated ceria uptake and retention in Kupffer cells with most of the internalized ceria as agglomerates (Figure 4A). Agglomeration of cytoplasmic nanoceria in the spleen appeared similar to the liver (Figure 4B). Considerable effort to detect nanoceria in hippocampus and cerebellum in 5 and $30 \mathrm{~nm}$ ceria-infused rats revealed only very rare electron dense particulates.

The results of more extensive investigation of ceria ENM localization, histological changes, and valence in the liver of these rats 30 days after $5 \mathrm{~nm}$ ceria administration were reported ${ }^{10}$. 
Intracellular ceria ENM agglomerates were seen in the cytoplasm of Kupffer cells, stellate cells, and hepatocytes that were usually membrane bound but not found within mitochondria or the cell nucleus. Electron energy loss spectrometry showed the ceria ENM had significant oxygen vacancies in the as-synthesized powder with little change after 30 days in situ in the liver ${ }^{8}$. 


\section{Discussion:}

Measurements of primary particle size (the smallest identifiable subdivision of the ENM), agglomerates, and aggregates are important to interpret the biological responses to ENM dosing. The distinction between agglomeration (in a suspension held together by physical [e.g., van der Waals or hydrophobic] or electrostatic forces) and aggregation (a cohesive mass consisting of particle subunits) is based on a NIST report ${ }^{11}$. TEM was the fundamental method for determining primary particle size and evaluating particle shape. High-resolution (scanning) TEM images of the 4 ceria ENMs showed none of the samples were aggregated ${ }^{9}$. The average primary particle diameters from the TEM analysis relate reasonably well to the BET surface area data (Table 2). Although not spherical, the hydrodynamic diameter of the ceria ENMs in the present study was only slightly larger than the TEM geometric diameter, as expected given the presence of citrate on the surface, which is expected to add $<1 \mathrm{~nm}$ to ENM diameter ${ }^{12}$.

We reported that the 15,30 , and $55 \mathrm{~nm}$ ceria ENMs investigated in the present study were rapidly cleared from blood ${ }^{9}$. This is supported by the significantly greater $\%$ of the $5 \mathrm{~nm}$ ceria dose in blood 1 and $20 \mathrm{~h}$ after its infusion compared to ceria in blood taken after the same elapsed times from rats that received the 3 larger ceria ENMs. The longer persistence of the 5 $\mathrm{nm}$ ceria ENM in blood may relate to its greater extent of citrate coating and/or its small size avoiding ready recognition by reticuloendothelial organs. The greater $\%$ of the $5 \mathrm{~nm}$ ceria dose in the brain than the $30 \mathrm{~nm}$ size at all times may relate to the greater $\%$ of the $5 \mathrm{~nm}$ ceria dose in the blood than the $30 \mathrm{~nm}$ size at all times. The rats in this work were not perfused to remove blood from their organs when terminated; therefore some of the brain cerium can be attributed 
to cerium in the blood in the vessels in the brain. Based on the rat brain vascular volume $(2 \%$ of the frontal cortex and $2.6 \%$ of gray matter) ${ }^{13}$ and cerium concentration in blood determined in this study, the cerium in the brain of ceria-ENM treated rats can be accounted for by the cerium in circulating blood only in rats terminated $1 \mathrm{~h}$ after dosing with the 5 and $30 \mathrm{~nm}$ ceria. This suggests some ceria ENM associated with the brain microvascular endothelial cells that present the first, and major, component of the BBB; pericytes; or astrocyte foot processes that comprise the BBB; or penetrated beyond those cells into brain parenchyma. Studies using the in situ brain perfusion method ${ }^{14}$ with a 2 min perfusion and a procedure to prepare a brain capillary poor fraction of brain parenchyma ${ }^{15}$ showed all of the $5 \mathrm{~nm}$ ceria to be in the brain parenchyma-poor fraction, suggesting it had not penetrated the BBB. Electron microscopy showed dense particles, presumably ceria ENM, lining the luminal side of brain microvascular endothelial cells, but none in brain parenchyma ${ }^{16}$. Extensive EM attempts to visualize the 5 and $30 \mathrm{~nm}$ ceria in the brain $1 \mathrm{~h}$ after its infusion provided little concrete evidence of ceria ENM in brain parenchyma. The \% of the dose of the $55 \mathrm{~nm}$ ceria was less in brain, spleen, and liver $20 \mathrm{~h}$ after infusion than after the smaller sized ceria ENMs. This is probably due to the accumulation of this largest, least citrate-surface stabilized ceria ENM at the site of its delivery into the vena cava, as visually observed.

The present results show considerable uptake by reticuloendothelial organs within $1 \mathrm{~h}$, with further uptake over the following $\sim 20 \mathrm{~h}$, and no significant reduction over the subsequent 30 days. The liver contained significantly more of the total dose of the 5 than $30 \mathrm{~nm}$ ceria at $20 \mathrm{~h}$ and the spleen contained significantly more of the $15 \mathrm{~nm}$ than the $5 \mathrm{~nm}$ ceria at 30 days, suggesting preferential clearance of smaller particles by the liver component of the 
mononuclear phagocyte system. Cerium concentration in healthy adult Chinese men who suffered sudden death was 100-fold higher in the liver than blood and intermediate in 16 other tissues, expect for lung, which was higher than liver. Compared to liver cerium concentration, spleen cerium was generally higher after ceria ENM in the present study, whereas in human spleen cerium was $\sim 5 \%$ of the liver cerium concentration, showing considerable difference between cerium retention from normal exposures and ENMs. Brain cerium was not determined in the human study ${ }^{17}$. The mean mass amount of cerium in the blood, liver, and spleen of ceria-treated rats among the 10 treatment groups of the present study ranged from 1.3 to 9044 -fold, 1410 to 34470 -fold, and 280 to 1180 -fold, compared to the overall mean of the non-ceria ENM treated rats. These results illustrate the increase and persistence of ceria in the liver and spleen due to the ceria ENM infusion. In contrast, brain cerium in ceria ENMtreated rats ranged from 0.26 - to 18 -fold of the overall mean of the non-ceria ENM treated rats. The apparent distribution of the $30 \mathrm{~nm}$ ceria ENM into the brain is consistent with prior finding of a commercial $\sim 30 \mathrm{~nm}$ ceria ENM in the brain, where it was found in the capillary lumen and in some of the adjacent astrocytes 1 and $20 \mathrm{~h}$ after its infusion ${ }^{7}$. After a much smaller dose of ceria ENM by the oral, intraperitoneal, and iv routes, cerium could not be detected in the brain of mice ${ }^{2}$. A small percentage of oral and intratracheal doses of ceria ENM was shown by ICPMS analysis to be in brain, but techniques, such as electron microscopy, were not utilized to determine its location ${ }^{3}$. The present and prior results suggest delivery of ceria ENM to the brain for therapeutic purposes will require a route of administration other than oral, inhalation, or iv; or drug delivery systems that cross the BBB, e.g., via receptor-mediated transport, the molecular trojan horse approach ${ }^{18}$. 
ENMs too large $(>5 \mathrm{~nm})$ to be excreted by the kidney ${ }^{19}$, are often retained for prolonged periods with little to no decrease in organ concentration ${ }^{20-27}$. We found $<0.5 \%$ of the dose of the $30 \mathrm{~nm}$ ceria used in this report was excreted in the urine and feces within the first 2 weeks ${ }^{8}$. Following intratracheal instillation, nanoceria concentrations in blood, bone, heart, kidney, liver, spleen, and testicle generally increased over 28 days, which could be due to continued translocation from the lung ${ }^{3}$. Blood and heart cerium decreased over 1 week after oral ceria ENM gavage but bone, brain, kidney, liver, lung, muscle, spleen, and testicle did not, showing no significant clearance from these organs ${ }^{3}$. The present findings show ceria, an insoluble metal oxide ENM, does not undergo significant clearance from the rat for at least 1 month.

The present results suggest the BBB protects the brain from ceria ENM circulating in the blood, and that a large iv dose of these ENMs did not greatly disrupt BBB integrity. The lack of brain entry suggests it will be challenging to deliver ceria ENM to the brain. This suggests surface coatings that facilitate flux across the BBB or non-traditional routes of drug delivery, such as uptake directly into the brain via cranial nerve terminals in the roof of the nasal cavity, might be necessary to deliver ceria ENM to the brain. The results suggest unintended exposure to ceria ENM should not result in significant brain uptake. The results also inform about the fate, up to 1 month, of ceria ENMs that are cleared from the blood; most reside in reticuloendothelial organs, where they are retained.

In summary, blood, brain, liver, and spleen cerium were determined 1 and $20 \mathrm{~h}$ and 30 days after iv infusion of $5,15,30$, and $55 \mathrm{~nm}$ ceria into the rat. Of the 4 sites, $\geq 98 \%$ was retained in the liver and spleen $20 \mathrm{~h}$ after its iv infusion, from which it was not significantly cleared over 30 
days. Intravenous ceria ENM infusion produced modest BBB disruption, as evidenced by increased brain fluorescein and horseradish peroxidase, not sufficient to allow appreciable brain ceria ENM entry. Electron microscopy revealed only occasional ceria ENM beyond the BBB. Nanoceria enters the brain poorly, even in the presence of minor opening of the BBB, consistent with studies of other insoluble metal-based ENMs ${ }^{28}$. This study was conducted with a large ceria ENM dose. The iv infusion of $85 \mathrm{mg} / \mathrm{kg}$, if distributed equally throughout the rat, would result in 495,000 $\mathrm{nM}$ ceria ENM (as shown in Table 1), which is within the range of ceria ENM concentrations employed in some in vitro studies. Given that a large percentage of ceria ENM is in mononuclear phagocyte system organs and some organs have much lower ceria levels, to as low as nearly zero in brain parenchyma (this study, ${ }^{2,8}$ ), this large ceria dose would be expected to produce concentrations of ceria in some organs similar to those found effective in some in vitro studies (Table 1). Given that this work was conducted with single, large ceria ENM doses, studies of smaller doses, repeatedly administered, as might better model of human exposure to ceria ENM as a therapeutic agent, are warranted. To advance ceria ENM as a therapeutic agent, studies of whole animal doses that produce the beneficial effects shown in vitro are needed. 


\section{Acknowledgements:}

The authors gratefully thank Rebecca L. Florence and Hamed Haghnazar for their contribution to this research and Matt $\mathrm{H}$. Hazzard for creation of the graphical abstract. 


\section{Figure legends:}

Figure 1. Primary particle size distribution of the four ceria ENMs determined by TEM. Figure 1A shows cummulative primary particle size distribution and the best fit log-normal function for the ENMs. Figure 1B shows the log-normal differential distribution model for each ENM.

Figure 2. Number- and volume-based particle size distribution of three of the ceria ENMs in aqueous supension determined by dynamic light scattering. Representative number-based (left panels) and volume-based (right panels) particle size distribution for ceria ENM aqueous suspensions. Panels $A$ and $B$ are $5 \mathrm{~nm}, \mathrm{C}$ and $\mathrm{D} 15 \mathrm{~nm}$, and $\mathrm{E}$ and $\mathrm{F} 30 \mathrm{~nm}$ ceria ENMs.

Figure 3. Percentage of the ceria ENM dose in the blood, brain, spleen, and liver. * Indicates a significant difference between treatment (shown) and control conditions (not shown). Bars over histograms note a significant difference in the percentage of the ceria dose between the two times.

Figure 4. Ceria ENM localization in liver and spleen after its infusion. The electron microscopic image in Panel A illustrates ceria agglomerates (arrows) within two Kupffer cells. Cytoplasmic accumulation of nanoceria (arrows) in a spleen cell is shown in the electron microscopic image in Panel B. Images are from rats infused with $5 \mathrm{~nm}$ ceria terminated 30 days after ceria infusion. 


\section{References}

1. Cassee FR, van Balen EC, Singh C, Green D, Muijser H, Weinstein J, Dreher K. Exposure, health and ecological effects review of engineered nanoscale cerium and cerium oxide associated with its use as a fuel additive. Crit Rev Toxicol 2011; 41: 213-29.

2. Hirst SM, Karakoti A, Singh S, Self W, Tyler R, Seal S, Reilly CM. Bio-distribution and in vivo antioxidant effects of cerium oxide nanoparticles in mice. Environ Toxicol 2011: 1-12.

3. He X, Zhang H, Ma Y, Bai W, Zhang Z, Lu K, Ding Y, Zhao Y, Chai Z. Lung deposition and extrapulmonary translocation of nano-ceria after intratracheal instillation Nanotechnology 2010; 21: 285103/1-/8.

4. Park E-J, Park Y-K, Park K. Acute toxicity and tissue distribution of cerium oxide nanoparticles by a single oral administration in rats Toxicological Research 2009; 25 : 79 84.

5. Geraets L, Oomen AG, Schroeter JD, Coleman VA, Cassee FR. Tissue Distribution of Inhaled Micro- and Nano-sized Cerium Oxide Particles in Rats: Results From a 28-Day Exposure Study. Toxicol Sci 2012; 127: 463-73.

6. Hirst SM, Karakoti AS, Tyler RD, Sriranganathan N, Seal S, Reilly CM. Anti-inflammatory properties of cerium oxide nanoparticles. Small 2009; 5: 2848-56.

7. Yokel RA, Florence RL, Unrine JM, Tseng MT, Graham UM, Wu P, Grulke EA, Sultana R, Hardas SS, Butterfield DA. Biodistribution and oxidative stress effects of a systemicallyintroduced commercial ceria engineered nanomaterial. Nanotoxicology 2009; 3: 234-48.

8. Yokel RA, Au TC, MacPhail R, Hardas SS, Butterfield DA, Sultana R, Tseng MT, Dan M, Florence RL, Unrine JM, Graham UM, Wu P, Grulke EA. Distribution, elimination and 
biopersistence to 90 days of a systemically-introduced $30 \mathrm{~nm}$ ceria engineered nanomaterial in rats. Toxicological Sciences 2012; 127: 256-68.

9. Dan M, Wu P, Grulke EA, Graham UM, Unrine JM, Yokel RA. Ceria engineered nanomaterial distribution in and clearance from blood: Size matters. Nanomedicine 2012; 7: 95-110.

10. Tseng MT, Lu X, Duan X, Hardas SS, Sultana R, Wu P, Unrine JM, Graham UM, Butterfield DA, Grulke EA, Yokel RA. Alteration of hepatic structure and oxidative stress induced by intravenous nanoceria. Toxicol Appl Pharmacol 2012; 260: 173-82.

11. Hackley VA, Ferraris CF. The use of nomenclature in dispersion science and technology. In: Technology NloSa, (ed.). 2001, p. 72.

12. Safi M, Sarrouj H, Sandre O, Mignet N, Berret JF. Interactions between sub-10-nm iron and cerium oxide nanoparticles and 3T3 fibroblasts: the role of the coating and aggregation state. Nanotechnology 2010; 21: 145103.

13. Ohno K, Pettigrew KD, Rapoport SI. Lower limits of cerebrovascular permeability to nonelectrolytes in the conscious rat. American Journal of Physiology 1978; 235: H299H307.

14. Takasato Y, Rapoport SI, Smith QR. An in situ brain perfusion technique to study cerebrovascular transport in the rat. American Journal of Physiology 1984; 247: H484-H93.

15. Triguero D, Buciak J, Pardridge WM. Capillary depletion method for quantification of bloodbrain barrier transport of circulating peptides and plasma proteins. Journal of Neurochemistry 1990; 54: 1882-8. 
16. Dan M, Tseng MT, Wu P, Unrine JM, Grulke EA, Yokel RA. Brain microvascular endothelial cell association and distribution of a $5 \mathrm{~nm}$ ceria engineered nanomateria. International Journal of Nanomedicine 2012; 7: 4023-36.

17.Zhu HD, Wang JY, Wu Q, Wang NF, Fan TJ, Liu HS, Liu QF, Wang XY, Ou-Yang L, Liu YQ, Xie Q. Elemental contents in organs and tissues of Chinese adult men. Chin Med Sci J 2007; 22: 71-82.

18. Patel MM, Goyal BR, Bhadada SV, Bhatt JS, Amin AF. Getting into the brain: approaches to enhance brain drug delivery. CNS Drugs 2009; 23: 35-58.

19. Choi HS, Liu W, Misra P, Tanaka E, Zimmer JP, Itty Ipe B, Bawendi MG, Frangioni JV. Renal clearance of quantum dots. Nat Biotechnol 2007; 25: 1165-70.

20. Ballou B, Lagerholm BC, Ernst LA, Bruchez MP, Waggoner AS. Noninvasive imaging of quantum dots in mice. Bioconjug Chem 2004; 15: 79-86.

21. Fischer HC, Liu L, Pang KS, Chan WCW. Pharmacokinetics of nanoscale quantum dots: in vivo distribution, sequestration, and clearance in the rat Advanced Functional Materials 2006; 16: 1299-305.

22. Yang RS, Chang LW, Wu JP, Tsai MH, Wang HJ, Kuo YC, Yeh TK, Yang CS, Lin P. Persistent tissue kinetics and redistribution of nanoparticles, quantum dot 705 , in mice: ICP-MS quantitative assessment. Environ Health Perspect 2007; 115: 1339-43.

23. Lin P, Chen JW, Chang LW, Wu JP, Redding L, Chang H, Yeh TK, Yang CS, Tsai MH, Wang HJ, Kuo YC, Yang RS. Computational and ultrastructural toxicology of a nanoparticle, Quantum Dot 705, in mice. Environ Sci Technol 2008; 42: 6264-70. 
24. van Ravenzwaay B, Landsiedel R, Fabian E, Burkhardt S, Strauss V, Ma-Hock L. Comparing fate and effects of three particles of different surface properties: $\mathrm{Nano}-\mathrm{TiO}_{2}$, pigmentary $\mathrm{TiO}_{2}$ and quartz. Toxicol Lett 2009; 186: 152-9.

25. Cho WS, Cho M, Jeong J, Choi M, Cho HY, Han BS, Kim SH, Kim HO, Lim YT, Chung BH. Acute toxicity and pharmacokinetics of $13 \mathrm{~nm}$-sized PEG-coated gold nanoparticles. Toxicol Appl Pharmacol 2009; 236: 16-24.

26. dos Santos Silva I, Malveiro F, Jones ME, Swerdlow AJ. Mortality after radiological investigation with radioactive Thorotrast: a follow-up study of up to fifty years in Portugal. Radiat Res 2003; 159: 521-34.

27. Cho W-S, Cho M-J, Jeong J-Y, Choi M-N, Han B-S, Shin H-S, Hong J, Chung B-H, Jeong J-Y, Cho M-H. Size-dependent tissue kinetics of PEG-coated gold nanoparticles. Toxicol Appl Pharmacol 2010; 245: 116-23.

28. Yokel Robert A, Grulke Eric A, MacPhail RC. Metal-based nanoparticle interactions with the nervous system: the challenge of brain entry and the risk of retention in the organism. Wiley Interdiscip Rev Nanomed Nanobiotechnol 2012; invited review, revision to be submitted August 17, 2012.

29. Dowding JM, Dosani T, Kumar A, Seal S, Self WT. Cerium oxide nanoparticles scavenge nitric oxide radical ( $(N O)$. Chem Commun (Cambridge, U K) 2012; 48: 4896-8.

30. Tarnuzzer RW, Colon J, Patil S, Seal S. Vacancy engineered ceria nanostructures for protection from radiation-induced cellular damage. Nano Letters 2005; 5: 2573-7.

31. Colon J, Herrera L, Smith J, Patil S, Komanski C, Kupelian P, Seal S, Jenkins DW, Baker $\mathrm{CH}$. Protection from radiation-induced pneumonitis using cerium oxide nanoparticles. Nanomedicine 2009; 5: 225-31. 
32. Colon J, Hsieh N, Ferguson A, Kupelian P, Seal S, Jenkins DW, Baker CH. Cerium oxide nanoparticles protect gastrointestinal epithelium from radiation-induced damage by reduction of reactive oxygen species and upregulation of superoxide dismutase 2 . Nanomedicine 2010; 6: 698-705.

33. Clark A, Zhu A, Sun K, Petty HR. Cerium oxide and platinum nanoparticles protect cells from oxidant-mediated apoptosis. J Nanopart Res 2011; 13: 5547-55.

34. Pagliari F, Mandoli C, Forte G, Magnani E, Pagliari S, Nardone G, Licoccia S, Minieri M, Di NP, Traversa E. Cerium oxide nanoparticles protect cardiac progenitor cells from oxidative stress. ACS Nano 2012; 6: Ahead of Print.

35. Niu J, Wang K, Kolattukudy PE. Cerium oxide nanoparticles inhibit oxidative stress and nuclear factor-kappaB activation in $\mathrm{H} 9 \mathrm{c} 2$ cardiomyocytes exposed to cigarette smoke extract. J Pharmacol Exp Ther 2011; 338: 53-61.

36. Shen S-g, Liu H-I, Wang W-y, Gu G-q, Zhou G-q. [Protection effects of $\mathrm{CeO}_{2}$ nanoparticles on A549 cells]. Hebei Daxue Xuebao, Ziran Kexueban 2011; 31: 160-6.

37. Lin W, Huang YW, Zhou XD, Ma Y. Toxicity of cerium oxide nanoparticles in human lung cancer cells. Int J Toxicol 2006; 25: 451-7.

38. Schubert D, Dargusch R, Raitano J, Chan SW. Cerium and yttrium oxide nanoparticles are neuroprotective. Biochemical and Biophysical Research Communications 2006; 342: 8691.

39. D'Angelo B, Santucci S, Benedetti E, Di Loreto S, Phani RA, Falone S, Amicarelli F, Ceru MP, Cimini A. Cerium oxide nanoparticles trigger neuronal survival in a human Alzheimer disease model by modulating BDNF pathway Current Nanoscience 2009; 5: 167-76. 
40. Das M, Patil S, Bhargava N, Kang JF, Riedel LM, Seal S, Hickman JJ. Auto-catalytic ceria nanoparticles offer neuroprotection to adult rat spinal cord neurons. Biomaterials 2007; 28: 1918-25.

41. Singh N, Cohen CA, Rzigalinski BA. Treatment of neurodegenerative disorders with radical nanomedicine. Ann N Y Acad Sci 2007; 1122: 219-30.

42. Estevez AY, Pritchard S, Harper K, Aston JW, Lynch A, Lucky JJ, Ludington JS, Chatani P, Mosenthal WP, Leiter JC, Andreescu S, Erlichman JS. Neuroprotective mechanisms of cerium oxide nanoparticles in a mouse hippocampal brain slice model of ischemia. Free Radical Biology \& Medicine 2011; 51: 1155-63.

43. Brunner TJ, Wick P, Manser P, Spohn P, Grass RN, Limbach LK, Bruinink A, Stark WJ. In vitro cytotoxicity of oxide nanoparticles: comparison to asbestos, silica, and the effect of particle solubility. Environmental Science and Technology 2006; 40: 4374-81.

44. Park EJ, Choi J, Park YK, Park K. Oxidative stress induced by cerium oxide nanoparticles in cultured BEAS-2B cells. Toxicology 2008; 245: 90-100.

45. Eom $\mathrm{HJ}$, Choi J. Oxidative stress of $\mathrm{CeO}_{2}$ nanoparticles via p38-Nrf-2 signaling pathway in human bronchial epithelial cell, Beas-2B. Toxicol Lett 2009; 187: 77-83.

46. Chen J, Patil S, Seal S, McGinnis JF. Rare earth nanoparticles prevent retinal degeneration induced by intracellular peroxides. Nat Nanotechnol 2006; 1: 142-50.

47. Zhou X, Wong LL, Karakoti AS, Seal S, McGinnis JF. Nanoceria inhibit the development and promote the regression of pathologic retinal neovascularization in the Vldlr knockout mouse. PLoS One 2011; 6: e16733. 
48. Kong L, Cai X, Zhou X, Wong LL, Karakoti AS, Seal S, McGinnis JF. Nanoceria extend photoreceptor cell lifespan in tubby mice by modulation of apoptosis/survival signaling pathways. Neurobiology of Disease 2011; 42: 514-23.

49. Amin KA, Hassan MS, Awad el ST, Hashem KS. The protective effects of cerium oxide nanoparticles against hepatic oxidative damage induced by monocrotaline. Int $J$ Nanomedicine 2011; 6: 143-9.

50. Niu J, Azfer A, Rogers LM, Wang X, Kolattukudy PE. Cardioprotective effects of cerium oxide nanoparticles in a transgenic murine model of cardiomyopathy. Cardiovasc Res 2007; 73: 549-59.

51. Park E-JC, Wan-Seob, Jeong J, Yi J-h, Choi K, Kim Y, Park K. Induction of inflammatory responses in mice treated with cerium oxide nanoparticles by intratracheal instillation. Journal of Health Science 2010; 56: 387-96.

52. Srinivas A, Rao PJ, Selvam G, Murthy PB, Reddy PN. Acute inhalation toxicity of cerium oxide nanoparticles in rats. Toxicol Lett 2011; 205: 105-15.

53. Hardas SS, Sultana R, Warrier G, Dan MF, R.L., Wu P, Grulke EA, Tseng MT, Unrine JM, Graham UM, Yokel RA, Butterfield DA. Rat brain pro-oxidant effects of peripherally administered $5 \mathrm{~nm}$ ceria 30 days after exposure. Neurotoxicology 2012. 
Figure 1.
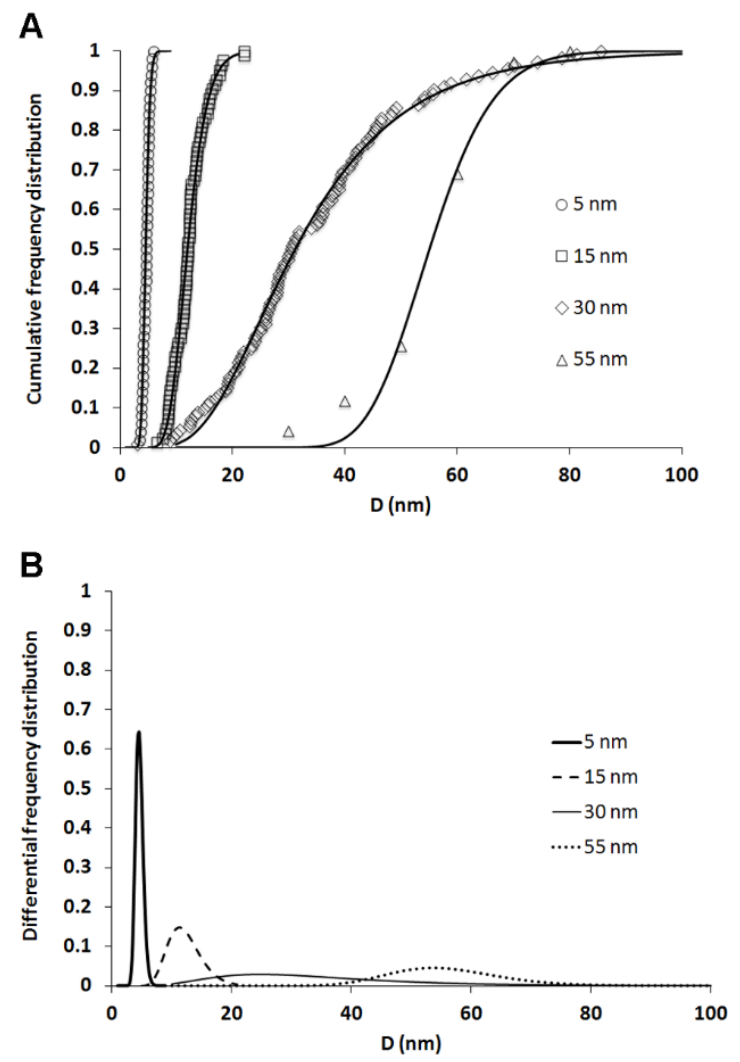
Figure 2.
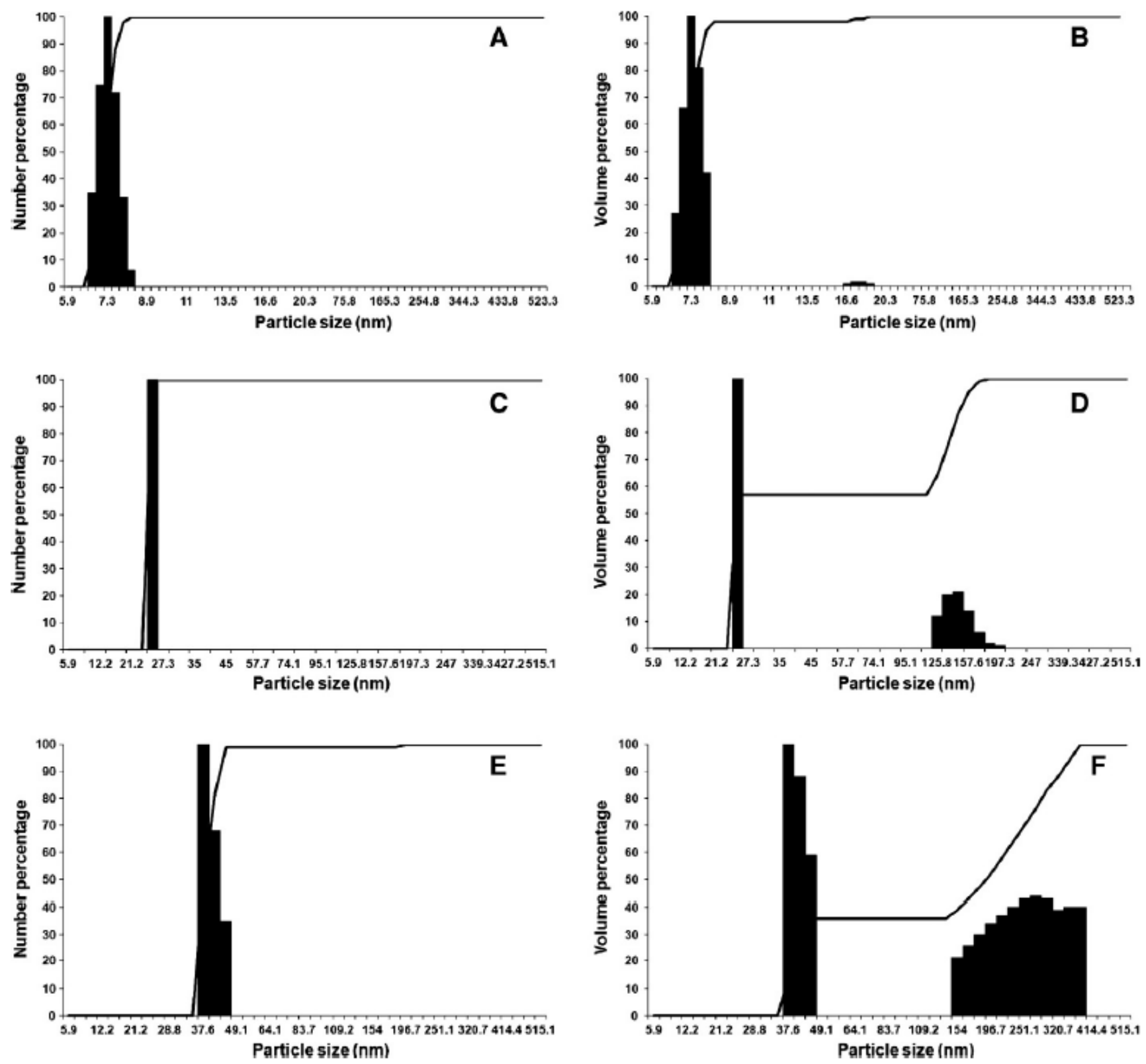
Figure 3.
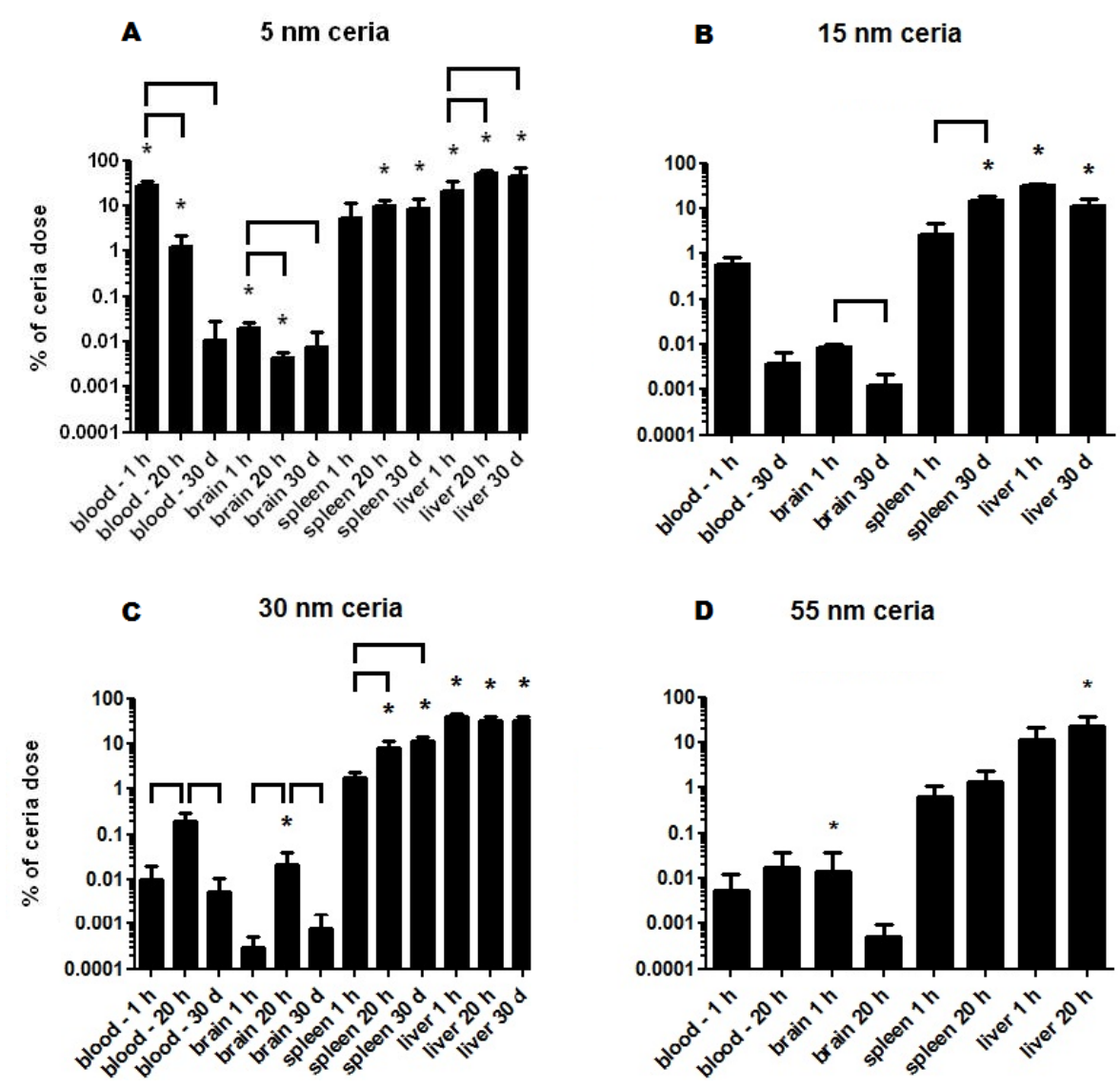

D $\quad 55 \mathrm{~nm}$ ceria

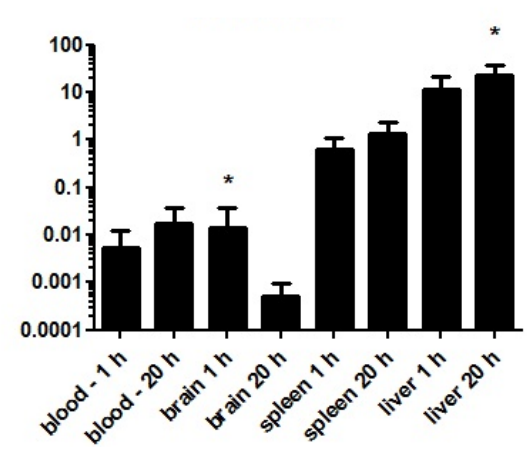


Figure 4 .
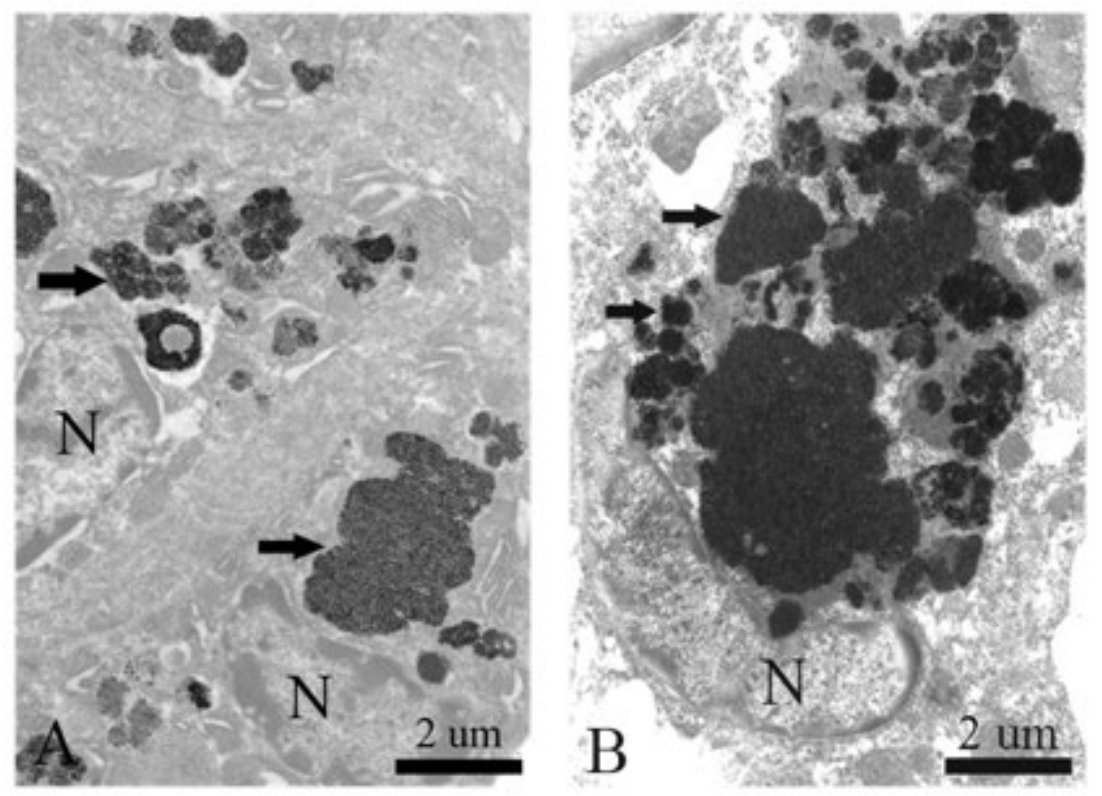
Table 1. Reports of ceria ENM effects.

\begin{tabular}{|c|c|c|c|c|c|}
\hline Study subject & $\begin{array}{c}\text { Ceria } \\
\text { ENM size } \\
(\mathrm{nm})\end{array}$ & $\begin{array}{c}\text { Ceria ENM } \\
\text { concentration } \\
(\mathrm{nM})\end{array}$ & Treatment & Effect & Ref \\
\hline \multicolumn{6}{|c|}{ In vitro studies reporting beneficial effects of ceria ENMs } \\
\hline Hemoglobin & 3 to 8 & $\begin{array}{l}50,000 \text { to } \\
1,000,000\end{array}$ & $\begin{array}{l}\text { Induction of nitric } \\
\text { oxide }\end{array}$ & Scavenging & 29 \\
\hline $\begin{array}{l}\text { MCF-7 breast tumor and } \\
\text { CCL-135 normal lung } \\
\text { fibroblast cells }\end{array}$ & 3 to 5 & 10 & $\begin{array}{l}\text { Radiation induced } \\
\text { cell damage }\end{array}$ & \begin{tabular}{|l|} 
Protection \\
\end{tabular} & $\begin{array}{l}30, \\
31\end{array}$ \\
\hline $\begin{array}{l}\text { CRL } 1541 \text { normal human } \\
\text { colon cell }\end{array}$ & 3 to 5 & 1 to 100 & $\begin{array}{l}\text { Radiation induced } \\
\text { cell damage }\end{array}$ & Protection & 32 \\
\hline $\begin{array}{l}\text { HT-1080 human breast } \\
\text { fibrosarcoma cells }\end{array}$ & 16 & $\begin{array}{l}1 \text { to } 10 \text {, but not } \\
100\end{array}$ & $\begin{array}{l}\text { Hydrogen peroxide- } \\
\text { induced apoptosis }\end{array}$ & Protection & 33 \\
\hline $\begin{array}{l}\text { Mouse-derived cardiac } \\
\text { progenitor cells }\end{array}$ & 5 to 8 & 59,000 to 290,000 & $\begin{array}{l}\text { Hydrogen peroxide- } \\
\text { induced injury }\end{array}$ & Protection & 34 \\
\hline $\begin{array}{l}\text { J774A.1 mouse } \\
\text { macrophages }\end{array}$ & 3 to 5 & 10,000 & $\begin{array}{l}\text { Lipopolysaccharide- } \\
\text { induced ROS }\end{array}$ & Reduction & 6 \\
\hline $\begin{array}{l}\text { Rat heart-derived } \\
\text { embryonic mocytes }\end{array}$ & & 10 & $\begin{array}{l}\text { Cigarette smoke } \\
\text { extract-induced ROS } \\
\text { and inflammation }\end{array}$ & Inhibition & 35 \\
\hline $\begin{array}{l}\text { A549 human basal } \\
\text { epithelial adenocarcinoma } \\
\text { cells }\end{array}$ & $\begin{array}{l}30,50 \text { and } \\
300\end{array}$ & 29,400 to 235,000 & $\begin{array}{l}\text { Viability and } \\
\text { hydrogen peroxide- } \\
\text { induced oxidation }\end{array}$ & $\begin{array}{l}\text { Increased viability, } \\
\text { decreased oxidation, } \\
\text { not size or dose } \\
\text { dependent }\end{array}$ & 36 \\
\hline A549 cells & 20 & 20,000 to 140,000 & & $\begin{array}{l}\text { Decreased viability via } \\
\text { oxidative stress }\end{array}$ & 37 \\
\hline $\begin{array}{l}\text { HT22 hippocampus derived } \\
\text { cells }\end{array}$ & 6 and 12 & $\begin{array}{l}\text { to } 120,000 ; \geq \sim \\
10\end{array}$ & Glutamate challenge & Enhanced cell survival & 38 \\
\hline $\begin{array}{l}\text { SH-Sy5Y neuroblastoma } \\
\text { cells }\end{array}$ & 6 to 16 & 600,000 & $\begin{array}{l}\text { A } \beta \text {-induced reduction } \\
\text { of cell viability }\end{array}$ & Reversal & 39 \\
\hline Rat spinal cord neurons & 3 to 5 & 10 & None & Enhanced viability & 40 \\
\hline $\begin{array}{l}\text { Mixed culture of rat cortical } \\
\text { neurons and glial cells }\end{array}$ & $\begin{array}{l}7,10, \text { and } \\
50\end{array}$ & 10 & $\begin{array}{l}\text { Hydrogen peroxide- } \\
\text { induced injury }\end{array}$ & Protection & 41 \\
\hline Mouse hippocampal slices & $\begin{array}{l}\text { Not } \\
\text { reported }\end{array}$ & 600 to 5000 & Ischemia model & Protection & 42 \\
\hline \multicolumn{6}{|c|}{ In vitro studies reporting adverse effects of ceria ENMs } \\
\hline $\begin{array}{l}3 \text { T3 rodent fibroblast and } \\
\text { MSTO- } 211 \mathrm{H} \text { human } \\
\text { mesothelioma cells }\end{array}$ & 19 & $\begin{array}{l}20,000 \text { to } 90,000 \\
\text { for } 6 \text { days or } \\
40,000 \text { to } 170,000 \\
\text { for } 3 \text { days } \\
\end{array}$ & & $\begin{array}{l}\text { Decreased viability and } \\
\text { DNA content }\end{array}$ & 43 \\
\hline $\begin{array}{l}\text { BEAS-2 human bronchial } \\
\text { epithelial cells }\end{array}$ & 15 to 45 & 6000 to 230,000 & & $\begin{array}{l}\text { Decreased viability, } \\
\text { death, and induction of } \\
\text { oxidative stress-related } \\
\text { genes }\end{array}$ & $\begin{array}{l}44, \\
45\end{array}$ \\
\hline \multicolumn{6}{|c|}{ In vivo studies reporting beneficial effects of ceria ENMs } \\
\hline Rats & 3 to 5 & \begin{tabular}{|l}
1 to $20 \mathrm{nmol}$ \\
injected into rat \\
vitreous humor
\end{tabular} & $\begin{array}{l}\text { Retinal neuron } \\
\text { hydrogen peroxide - } \\
\text { induced ROS }\end{array}$ & & 46 \\
\hline $\begin{array}{l}\text { Knockout mice that develop } \\
\text { intra-retinal and sub-retinal } \\
\text { neovascular lesions }\end{array}$ & 3 to 5 & $\begin{array}{l}172 \mathrm{nmol} \text { bilateral } \\
\text { intraocular } \\
\text { injection } \\
\text { post-natal day } 7\end{array}$ & & $\begin{array}{l}\text { Inhibited ROS } \\
\text { production and lesion } \\
\text { formation }\end{array}$ & 47 \\
\hline
\end{tabular}




\begin{tabular}{|c|c|c|c|c|c|}
\hline & & $\begin{array}{l}172 \mathrm{nmol} \text { bilateral } \\
\text { intraocular } \\
\text { injection } \\
\text { post-natal day } 28\end{array}$ & & Reduced lesions & 47 \\
\hline $\begin{array}{l}\text { Mouse model of retinal } \\
\text { degeneration }\end{array}$ & $\begin{array}{l}\text { Not } \\
\text { reported }\end{array}$ & $\begin{array}{l}20 \text { nmol into the } \\
\text { heart post-natal } \\
\text { days } 10,20 \text {, and } \\
30\end{array}$ & & Decreased retinal ROS & 48 \\
\hline Rats & 25 & $\begin{array}{l}0.0001 \mathrm{nmol} / \mathrm{kg} \\
\text { on days } 1,3,5 \\
\text { and } 7\end{array}$ & $\begin{array}{l}\text { Monocrotaline- } \\
\text { injection on day } 4 \\
\text { induced } \\
\text { hepatotoxicity }\end{array}$ & Protection & 49 \\
\hline Athymic nude mice & 3 to 5 & $\begin{array}{l}0.06 \mathrm{nmol} / \mathrm{kg} \\
\text { thrice weekly ip } \\
\text { for } 2 \text { weeks }\end{array}$ & $\begin{array}{l}\text { Radiation-induced } \\
\text { lethality }\end{array}$ & Reduction & 31 \\
\hline $\begin{array}{l}5 \text { week old transgenic } \\
\text { mouse model of } \\
\text { cardiomyopathy }\end{array}$ & 7 & $\begin{array}{l}\sim 300 \mathrm{nmol} / \mathrm{kg} \\
\text { twice weekly iv for } \\
2 \text { weeks }\end{array}$ & & $\begin{array}{l}\text { Partially converted } \\
\text { cardiac function to } \\
\text { control levels }\end{array}$ & 50 \\
\hline \multicolumn{6}{|c|}{ In vivo studies reporting adverse effects of ceria ENMs } \\
\hline Mice & $\sim 130$ & $\begin{array}{l}290,000 \text { to } \\
2,325,000 \\
\text { nmol/kg } \\
\text { intratracheal } \\
\text { instillation }\end{array}$ & & $\begin{array}{l}\text { Neutrophil elevation } \\
\text { and inflammatory } \\
\text { cytokines in the } \\
\text { bronchoalveolar fluid, } \\
\text { lung granulomas } 7 \text { and } \\
14 \text { days later }\end{array}$ & 51 \\
\hline Rats & 15 to 30 & $\begin{array}{l}641 \mathrm{mg} / \mathrm{m}^{3} \\
\text { inhalation for } 4 \mathrm{~h}\end{array}$ & & $\begin{array}{l}\text { Increased oxidative } \\
\text { stress } 1,2 \text { and } 14 \text { days } \\
\text { later }\end{array}$ & 52 \\
\hline Rats & 30 & $\begin{array}{l}290,000 \text { to } \\
4,350,000 \\
\mathrm{nmol} / \mathrm{kg} \text { iv }\end{array}$ & & $\begin{array}{l}\text { Kupffer cell activation } \\
\text { and brain oxidative } \\
\text { stress }\end{array}$ & 7 \\
\hline Rats & 5 & $\begin{array}{l}495,000 \mathrm{nmol} / \mathrm{kg} \\
\text { iv }\end{array}$ & & $\begin{array}{l}\text { Oxidative stress in the } \\
\text { brain } 30 \text { days later }\end{array}$ & 53 \\
\hline Rats & 5 & $\begin{array}{l}495,000 \mathrm{nmol} / \mathrm{kg} \\
\text { iv }\end{array}$ & & $\begin{array}{l}\text { Hepatic granuloma, } \\
\text { apoptosis and oxidative } \\
\text { stress } 30 \text { days later }\end{array}$ & 10 \\
\hline Rats & 30 & $\begin{array}{l}495,000 \mathrm{nmol} / \mathrm{kg} \\
\text { iv }\end{array}$ & & $\begin{array}{l}\text { Hepatic granuloma } 30 \\
\text { and } 90 \text { days later, } \\
\text { oxidative stress in liver } \\
\text { and spleen }\end{array}$ & 8 \\
\hline
\end{tabular}


Table 2. Characteristics of the ceria ENMs

\begin{tabular}{|c|c|c|c|c|c|c|}
\hline $\begin{array}{c}\text { Ceria } \\
\text { ENM } \\
\text { Primary } \\
\text { Particle } \\
\text { Size } \\
(\mathrm{nm})\end{array}$ & Shape & $\begin{array}{c}\text { BET } \\
\text { Surface } \\
\text { Area } \\
{\left[D_{32}{ }^{\mathrm{A}}\right]}\end{array}$ & $\begin{array}{c}\text { Average } \\
\text { Primary } \\
\text { Particle Size: } \\
\text { TEM Dave } \pm \\
\text { S.D., }\left\{D_{32}{ }^{B}\right\}\end{array}$ & $\begin{array}{c}\text { Average Particle } \\
\text { Size in Water } \\
\text { Number basis } \\
\text { [Volume basis] }\end{array}$ & $\begin{array}{c}\text { Zeta } \\
\text { Potential in } \\
\text { Water }\end{array}$ & $\begin{array}{c}\text { Extent of } \\
\text { Surface } \\
\text { Citrate } \\
\text { Coating }\end{array}$ \\
\hline 5 & polyhedral & $\begin{array}{c}121 \\
\mathrm{~m}^{2} / \mathrm{g} \\
{[6.5 \mathrm{~nm}]}\end{array}$ & $\begin{array}{c}4.6 \pm 0.135 \\
n m \\
\{4.8 \mathrm{~nm}\}\end{array}$ & $\begin{array}{c}7 \mathrm{~nm} \\
{\left[\begin{array}{c}98 \%, \\
\mathrm{~nm} ; 2 \%, 18\end{array}\right.}\end{array}$ & $\begin{array}{l}-53 \pm 7 \mathrm{mV} \\
\text { at } \mathrm{pH} \sim 7.35\end{array}$ & $\sim 40 \%$ \\
\hline 15 & polyhedral & $\begin{array}{l}71 \mathrm{~m}^{2} / \mathrm{g} \\
{[11 \mathrm{~nm}]}\end{array}$ & $\begin{array}{c}12.0 \pm 0.232 \\
n m \\
\{13.5 \mathrm{~nm}\}\end{array}$ & $\begin{array}{l}25 \mathrm{~nm} \\
{[57 \%, 25 \mathrm{~nm} ; 43 \%} \\
145 \mathrm{~nm}]\end{array}$ & $\begin{array}{l}-57 \pm 5 \mathrm{mV} \\
\text { at } \mathrm{pH} \sim 7.3\end{array}$ & $\sim 27 \%$ \\
\hline 30 & cubic & $\begin{array}{l}15 \mathrm{~m}^{2} / \mathrm{g} \\
{[52 \mathrm{~nm}]}\end{array}$ & $\begin{array}{c}31.2 \pm 0.478 \\
\mathrm{~nm} \\
\{51 \mathrm{~nm}\}\end{array}$ & $\begin{array}{c}41 \mathrm{~nm} \\
{[36 \%, 41 \mathrm{~nm} ; 64 \%} \\
273 \mathrm{~nm}]\end{array}$ & $\begin{array}{l}-56 \pm 8 \mathrm{mV} \\
\text { at } \mathrm{pH} \sim 7.3\end{array}$ & $\sim 18 \%$ \\
\hline 55 & polyhedral & & $\begin{array}{c}55.0 \pm 0.162 \\
\mathrm{~nm} \\
\{59 \mathrm{~nm}\} \\
\end{array}$ & & $\begin{array}{l}-32 \pm 2 \mathrm{mV} \\
\text { at } \mathrm{pH} \sim 7.3^{\mathrm{C}}\end{array}$ & $\sim 15 \% \mathrm{c}$ \\
\hline
\end{tabular}

